\title{
16 A multilingual approach to the history of Standard English
}

\section{Introduction}

This paper focuses on three developmental stages in the history of English which are apparent from a multilingual perspective but which are currently omitted from textbooks: the late medieval mixed-language business system, the fifteenth century tip-point when the switchover to English was imminent, and the subsequent shift to Proto-Standard English. I survey recent work which shows a disruption phase in the last few decades of the fourteenth century in both Anglo-Norman and mixed-language writing. Starting with this disruption phase around the 1370s and continuing to the tip-point to monolingual English around the 1480s (the dating is not concrete, it varies from archive to archive, but roughly fits these parameters), I argue that the intervening century constitutes a period of transition from Medieval Latin to Proto-Standard English.

\section{Three developmental stages as viewed from a multilingual perspective}

Prior to the fifteenth century, Londoners (and people elsewhere in Britain) kept accounts not in monolingual English, but in either a Medieval Latin or AngloNorman French matrix, with English (and sporadic words from other languages) embedded in a syntactically orderly manner. Certain linguistic elements were particularly resistant to representation in Medieval Latin or Anglo-Norman. Names of people, their social ranks and titles, place-names, currencies weights and measures, and the names of specific traded commodities were likely to be retained in their original form. Nouns and deverbal -ing forms could, noncategorically, appear in English. Illustration is given with some extracts from the London merchant and moneylender Gilbert Maghfeld's account-book for the years 1372-1395. The main matrix language (that is, the syntactic framework) is Anglo-Norman:

Acknowledgment: My grateful thanks to Jeremy Smith and Julia Fernández Cuesta for their stringent and constructive criticisms, and to José Miguel Alcolado Carnicero for permission to use his diagram.

DOI 10.1515/9781501504945-016 
fo 9v: It rec p Marĝy $M$ xiij tymb de cristy grey $p^{2} c^{\circ}$ le tȳb .vj. $s^{2}$ 'Item, received from Margery M 13 timbers of cristy grey, price the timber: 6s' fo 10v: John fflukke \& John Joys de Wollewych doient en le .vj. io ${ }^{\sigma}$ de Sept pur j petit boot appelle Goodhale apayer al ffeste de Pasch [...]

'John Flukke and John Joys of Woolwich owe on the 7th day of Sept for 1 little boat called "Goodhale", to pay at Easter [...]'

fo 14: $\mathrm{Me}^{d} \hat{q}$ en le ij io ${ }^{\sigma}$ de dit mois iay paye pur Rog Ayschbournh ${ }^{\sigma} m p^{\sigma}$ le Scheryngg de son lyuie achate de si taylo ${ }^{\sim}$ ijs vijd ob 'Memo, that on the 2nd day of the said month, I pay for Roger Ayschbournham for the shearing of his livery bought from his tailor, 2s $7 d$ 1/2'

fo 33v: Med $\hat{q}$ Joh ffluk de Wollewich doit en vaitt de Seint Mich $p^{\sigma}$ j verybot $p^{\sigma}$ chescun semain vijd

'Memo, that John Fluk of Woolwich owes on St Michael's eve for one ferryboat, for each week, $7 \mathrm{~d}$ '

fo 34: $\mathrm{Me}^{d} \hat{q}$ Gybon Maufeld ad paye $\mathrm{p}^{\sigma}$ John Gower Esquier a j Schippman $p^{\sigma}$ freit dune braspott mis $p$ tre de lyne ies $\hat{q} s$ a loundrs 'Memo, that Gybon Maufeld pay by John Gower Esquire 1 shipman for freight of a brass pot, sent by letter from Lynn to London'

(The National Archives, E101/509/19, Gilbert Maghfeld’s “A Merchant’s Account Book")

The English components are:

$\begin{array}{ll}\text { names of people: } & \begin{array}{l}\text { Margy M, John fflukke/ffluk, John Joys, Rog' } \\ \text { Ayschbournh }{ }^{a} m, \text { Gybon Maufeld, John Gower }\end{array} \\ \text { names of places: } & \text { Wollewich, lyne } \\ \text { social ranks and titles: } & \text { Esquier } \\ \text { weights and measures: } & \begin{array}{l}\text { tymb < OFr timber }<\text { Gmc 'bundle of furs, usually } \\ 40 \text { skins' }\end{array} \\ \text { commodities (NPs): } & \text { cristy grey, }{ }^{1} \text { boot, verybot, scheryngg, braspott }\end{array}$

1 Middle English Dictionary, cristi-grei (n.) 'A gray fur with tufts, or crests, of some kind', first attested in 1378. See Wright (2002) for discussion of Gilbert Maghfeld's placement of adjectives both fore and aft of the noun in the Noun Phrase. 
Visual diamorphs (that is, words belonging to both English and French) ${ }^{2}$ are: It, rec, pc, \&, Sept, ffeste, $\mathrm{Me}^{d}$, lyu'e, taylo ${ }^{\sigma}$, Seint Mich, Esquier, freit, tre. The distribution of the two languages is not random. Nouns, deverbal -ing forms and adjectives may optionally appear in English; but prepositions, conjunctions and pronouns must appear in the matrix language, which in this case is AngloNorman (Maghfeld could have chosen Medieval Latin as his matrix, as he occasionally did elsewhere in his account-book). So long as English words are assimilated into the Anglo-Norman text by taking inflections, by not taking up their native mutations, and by taking abbreviation and suspension signs which enable the reading of inflections as operative in both French and English, the morphological integrity of the base Anglo-Norman text is not compromised. This process was facilitated and enabled by visual diamorphs. The medieval abbreviation and suspension system optimised possibilities of visual diamorphs, and financial accounts show the highest frequency of visual diamorphs of any contemporaneous text-type. The principle of merging matter that can be merged was crucial to this variety, and this poses a challenge for theories of codeswitching which depend on there being two distinctly-maintained opposing codes (e.g. Myers-Scotton 1993). Medieval business mixed-language writing is not alone in this; for example, a correlative phenomenon has been identified by Picone (1994) in spoken Louisianan French, where speakers produce forms that belong neither uniquely to English nor uniquely to French but to both at once, which Picone calls a "code-intermediate" state. Also relevant is Clyne's work (e.g. Clyne 1967, 1991, 2003) on words of similar phonetic shape in both languages triggering a switch from one to the other. Nonetheless, business mixedlanguage as written in medieval Britain is unlike the kind of data usually studied by synchronic linguists in that the switch-points are predictable, although not categorically implemented.

The mixed-language system changed over time, as do all languages in use. Ratios of English nouns premodified by English adjectives leading to multicomponent English Noun Phrases increased gradually over the fourteenth and early fifteenth century. There was a tendency to move away from synthetic case inflexion and towards prepositional particles, following the drift towards analycity found in Medieval Latin, Anglo-Norman and English of the time. In the 1420s in the Latin-matrix accounts of London Bridge, the definite article la began to be

2 The definition of visual diamorphs is the overlapping of two (or more) written codes into forms which are simultaneously both (or all) (see Wright 2011: 203). 
used, although not signalling gender. ${ }^{3}$ Here is an extract from a text at the tip-point (in Dorian's [1978, 1981] terminology, where a previously stable language undergoes a sudden change immediately before it dies out altogether), taken from a Port of London Medieval Latin-matrix customs account of 7 March 1481:

\begin{abstract}
Petro Segir al p j Cista j basket j pp ${ }^{a}$ \& j wirkyn̂ Cû viij do $\beta$ \& ij ßtomhatte vj brusshis .ijC lb filyng vij do $\beta$ fit blod $v$ do $\beta$ \& dī hatt Carde .vj par volle Carde iiij Sôme nayle .xiiij doß pelt .ij panū depict .xiiij doß ßtomihatte ij $\mathrm{g}^{\circ} \mathrm{S}$ Cirotece \& $x$ hatter stockkys prec $x x^{l \bar{\imath}} x_{i i j}{ }^{s}$ iiij $^{d}$

'Peter Segir, alien, 1 chest 1 basket 1 pipe 1 firkin with 8 doz. 2 Saint Omer hats, 6 brushes, 200 lbs filings, 7 doz. blue (or perhaps 'blood-coloured') thread, 51/2 doz. hatters' cards, 6 pairs wool cards, 4 sums nails, 14 doz. skins, 2 painted cloths, 14 doz. Saint Omer hats, 2 gross gloves, 10 hatters' stocks, £20 13s 4d'
\end{abstract}

(The National Archives, E122/194/25, translation in Cobb [1990: no. 93])

The English words are: basket, wirkyn̂, ßtomihatte, brusshis, filyng, hate, volle, sôme, nayle, hatter, stockkys and the visual diamorphs are: at, \&, th, blod, $d \bar{\imath}$, carde, par, do $\beta, g^{o} s, l \bar{l}, \hat{s}, d .^{4}$ This leaves only monolingual Latin Petro, p, cista, $p^{a}{ }^{a}, c \hat{u}$, fit, pelt, panu, depict, cirotec $_{e}$, prec, so that monolingual Medieval Latin is no longer the predominant language (at a ratio of 3:1, excluding numbers). The text consists of three-quarters of words that can be read as English and a quarter Latin, rather than the other way around. Here is another extract from the same day's entry:

3 See Wright (2010a) for a discussion. In the [Medieval Latin + English] London Bridge House Estate records of the first half of the fifteenth century, the definite article le preceded a following English noun, and blocked a following Latin suffix on that noun. Definite article la occurred only in the prepostional phrase de la, without signalling a following feminine noun. In the fifteenth century [Anglo-Norman + English] London Merchant Taylors' Company documents, the definite article le signalled both a following English noun as well as a French one, but the definite article la was not usually followed by an English noun (French nouns could be qualified by both $l e$ and $l a$ in close proximity). Thus, gender was not marked by articles in this text type at this place and point in time.

4 volle card antedates the Oxford English Dictionary's wool-card, n., first attested 1564; hatt(er(s card, hatter stock have no OED entry, but cf. OED card, n.1 "2. a. An instrument with iron teeth, used in pairs to part, comb out, and set in order the fibres of wool, hemp, etc., one of the cards being held in the hand, and the other fastened to a 'stock' or support." 
Anthonio de la hay al p pp $p^{a}$ Cum .iiij. complet harneys . j bar ${ }^{2} \hat{u} x x x$ par wolle carde $j$ bottôn of a basyn̂ $j$ bar wyn lyes . j bras pott. di bar' Cû $C$ tb fyling p $c x . \hbar \bar{\imath} \cdot x j .{ }^{s}$ iij $^{d}$

'Anthony de la Hay, alien, 1 pipe with 4 complete harnesses, 1 barrel with 30 pairs wool cards, 1 bottom of a basin, 1 barrel wine lees, 1 brass pott, half a barrell with 100 lbs filings, price £10 11s 4d'

(The National Archives, E122/194/25, translation in Cobb [1990: no. 82])

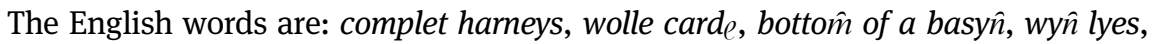
bras pott; the visual diamorphs are: at, bar, par, dî, $t \hat{b}, p c c, t i, s, d$; and monolingual Medieval Latin: Anthonio, $p, p p^{a}$, cum. The medieval system of Romance matrix-language plus English nouns, modifiers and stems of verbs is shifting. English premodified noun phrases are default, as opposed to earlier switching between English nouns and Latin or Anglo-Norman nouns, switching between English modifiers and Latin or Anglo-Norman modifiers, and switching between pre- and post-modification; and there is a prepositional phrase in English, bottom of a basyn, which is not part of the traditional system. It confirms that the tip-point has been reached. Previously, prepositions would always have been realised in the Romance matrix language, but here English is encroaching on function words too. The code-switched mixed-language system was about to be abandoned, and we see transgression of the switchpoint rules in the writing of the pre-shift generation, so our customs clerk of 1481 is just at that pre-shift point. However, because different institutions shifted from the mixed-language system to monolingual English in different decades between 1380 and 1480, the "pre-shift generation" cannot be dated to a specific set of twenty-five years; it took place gradually over more than a century, and several archives (including the Brewers', the Grocers', the Mercers' livery companies) show considerable toing and froing between mixed-language and monolingual English before eventually settling down to monolingual English. ${ }^{5}$ Indeed several years' worth of monolingual English entries can be followed by a resumption of mixed-language writing, or sporadic return to Latin phrases and formulae, and all this characterises the tip-point, which looks a little different in each individual archive. It is not yet known how long this pre-shift disruption lasted, or whether it lasted

5 See Alcolado Carnicero (2014) and Metcalfe (2014) for descriptions of the Mercers' and Brewers' livery company records respectively, and Wright (2002) for analysis of the tip-point in the Mercers' archive. Miller (1997: 252-256) uses text from the tip-point of the Grocers' Company records as evidence of hybrid Anglo-Norman and English lexemes in order to build an argument about the preponderance of hybrid forms in Middle English. 
for more than one generation in each case. The tip-point is not described in textbooks on the development of the history of the English language, and yet it is easily discernible, and there is plenty of evidence for it. The reason, presumably, is because only monolingual English texts have been deemed worthy of notice, even though mixed-language texts from the tip-point contain large amounts of sustained English.

By around 1500 the most laggardly, conservative institutions had finally tipped over into monolingual English (those in the van preceded them by a hundred years, so Gilbert Maghfeld's text of 1372-1395 was in keeping with all but the most radical of his contemporaries). When the tip-point had become a thing of the past, and the toing and froing between mixed-language accounts and monolingual English ones was over, monolingual English was the outcome but it was not yet Standard English. Standard English is not regionally marked, and it does not admit of (much) spelling variation, whereas the kind of monolingual business English used in London immediately after the transition period was still southern in its morphology and graphies:

This is the acconte of Thomas kytson and Robart Browne Chyrche wardeins of the pesch Chyrch of Seint Mary Mawdellens in Mylkestret in london \& Rule ${ }^{a}$ is of the goods \& ornaments that is to say from $A^{o} d n \bar{\imath} x V^{C}$ xix vnto anno $d n \bar{\imath} x v^{C} x x^{t i}$ which is a hole yere as apperyt by this Charge and discharge as heraft ffollowith (Guildhall Library, London. MS 2596/1, fo 9. 1519-20. St Mary Magdalen Milk Street Cash Book, 1518-1606. Churchwardens' Accounts.)

Verb morphology is still southern -th (apperyt, ffollowith) in this cash-book, even though $-s$ was a London variant by 1520, albeit at low frequencies, and spellings are mostly not those which would later become accepted as standard. ${ }^{6}$

In sum, the late medieval default was the business mixed-language system with its highly-regulated switchpoints, followed by a period of transition beginning in the late fourteenth century, culminating in transgressive switches at the tip-point, including shifts back and forth between monolingual English and mixed-language writing, followed by a tip to monolingual Proto-Standard English, all more or less completed by the late fifteenth century. It was a three-stage switchover: mixed-language, to transition period, to monolingual English. Then, there was a good two hundred years in which firstly elimination of variants took place, and subsequently selection of single, correct words and spellings (which

\footnotetext{
6 Third-person indicative present-tense $-s$ is found in London texts as early as the 1370s, but it remained a minority variant until the 1570 s, not becoming dominant until the 1640s-1710s (Lass 1992: 138-139, 1999: 162-165; Nevalainen and Raumolin-Brunberg 1996: 104-107).
} 
process was still playing out over the eighteenth century). ${ }^{7}$ Essentially, in mercantile writing in England before 1480, English was the foreign language, but because code-switching was default, English was visually present, and indeed obligatory in syntactically and semantically-regulated sites. But one needs to have a multilingual perspective in order to see it.

\section{On textbook accounts of the origins of Standard English}

None of this is mentioned in textbook accounts of the rise of Standard English. Wright (1996) surveyed textbook explanations of its origins, and pointed out some inconsistencies and unlikelihoods - which inconsistencies and unlikelihoods still tend to be repeated. The orthodox version goes like this: a pre-Standard written spelling-system called "Chancery Standard" evolved from either the East Midlands dialect (according to Ekwall [1956] and subsequent followers) or the Central Midlands dialect (according to Samuels [1963] and subsequent followers). It stemmed from scribes writing in the King's Office of Chancery, and it was the ancestor of Standard English. It was the result of wealthy and influential, although not numerous, East (or Central) Midlanders who had migrated to London, and caused the Londoners to shift their dialect. That this is an unlikely scenario can be argued thus:

Following earlier scholars Morsbach (1888) and Heuser (1914), Ekwall (1956: xi-lxviii) offered an explanation for fourteenth-century changes in London spellings for vowels in stressed syllables, which shifted from "Saxon" to "Anglian" (Wright 1996: 104). Ekwall wondered whether this change from Southern dialect to an apparently more Anglianised one might be due to Northerners' migration to London. To prove his theory one way or the other he culled locative surnames from early fourteenth-century London tax-lists and plotted them on a map to see where they came from. Obviously, this methodology is skewed: not all surnames are locative; of those that are, a parent, grandparent or godparent might have come from the place in question rather than the tax-list bearer; the bearer might have been an apprentice who received the locative surname from a master, having nothing to do with the master's family linguistically; and place-names often repeat, so that a Londoner (or ancestor, godparent or master) with Sudbury as part of their surname may have originated in Sudbury in Middlesex, or

7 It is this latter stage where the new technology of printing, followed by the rise of prescriptivism, putatively had an effect. 
Sudbury in Suffolk, with no way of knowing which. Ekwall was fully aware of all of these drawbacks:

I came to the tentative conclusion that so far as can be judged from the Subsidy Rolls, the contribution to the London population from Southern counties about the beginning of the fourteenth century was larger than that from the Midland counties, and that the Midland character of the later London language could hardly be due to immigration on a larger scale from the Midlands than from the South (Ekwall 1956: xii-xiii).

This would seem to be categorical: "The aggregate figure for the Home Counties" (i.e. the counties around London - $L C W$ ) "is about 3,000 persons, thus about the same as that for the Midlands and the North taken together" (Ekwall 1956: lx). Ekwall was quite clear that his survey, imperfect as it was, did not support the theory of large numbers of immigrants from places North of London as an explanation as to why Northern spellings should have started to be used in London in the later fourteenth-century. "The question may then be raised whether it is probable that linguistic influence due to immigration from the Midlands and the North can have been sufficiently strong to affect the City dialect" (Ekwall 1956: lx). Ekwall suggested that the migration theory could still be salvaged, however, by positing post-1300 immigration of upper-class Midlanders into London. He assumed that mayors, aldermen and sheriffs would have belonged to the upper class (1956: lxii), and that wealthy, important and influential Midland and Northern mayors, aldermen, and senior livery-company men settled in London in the relevant period (albeit not in great numbers), and that they would not have understood Londoners' pronunciations:

Pronunciations such as the Southern eld, cheld, for old, cold would not be readily understood in the Midlands and would be avoided. This accounts for the early disappearance of cheld from the London language. To sum up, the London language as we find it towards the end of the fourteenth century was a class dialect, the language spoken by the upper stratum of the London population (Ekwall 1956: 1xiii).

A proto-sociolinguist, Ekwall identified some of these wealthy, influential and important Northern and Midland members of the Court of Aldermen and the Court of the Common Council, but he did not contextualise them against the more numerous and equally important members from London and elsewhere. Since 1956 there has been a wealth of sociolinguistic investigation revealing that speakers do not usually emulate the speech-ways of the upper classes (if being a City office-bearer or Common Councilman was indeed coterminous with being upper-class), and that the speechways of the population already in situ would have been more likely to have prevailed. Ekwall's theory is inherently unlikely, and he did, in fact, suggest an alternative: "the marked East Midland 
element in the London language may to some extent be bound up with the fact that this part of England was the old Danelaw" (Ekwall 1956: lxviii).

Seven years later, Michael Samuels published a highly influential paper which established the term "Chancery Standard" (Ekwall's phrase was "Westminster Standard”) as the precursor of Standard English. Samuels was primarily interested in spelling variants of common words, because he was surveying monolingual English manuscripts in order to plot spelling variation across Britain, which was to culminate in the monumental Linguistic Atlas of Late Medieval English of 1986. He categorised fourteenth and fifteenth-century texts containing specific spelling practices into four "types". Type 1 consisted of religious Wycliffite writings of mainly Central Midland and Southern provenance. Type 2 spellings are found in a small group of fourteenth-century manuscripts produced somewhere near London which contain spellings commensurate with those found in the English Proclamation of Henry III, that is, of "early Essex-type" (Samuels [1963] 1989: 70). Type 3 spellings are found in the works of Chaucer, Gower and Hoccleve, and some of the civic documents in Chambers and Daunt (1931) and the wills in Furnivall (1882). Type 4 ("which I shall call 'Chancery Standard"”) documents were those produced by the Office of Chancery, the royal secretariat; "that flood of government documents that starts in the years following 1430 [...] it is this type, not its predecessors in London English, that is the basis of modern written English" (Samuels 1989: 71). Samuels rejected Ekwall's suggestion of East Anglia (the wealthiest part of the Midlands, from which important and influential Midlanders might have been expected to come) as a likely provenance for these spellings, as Type 4 spellings do not match those in A Linglistic Atlas of Late Mediaeval English (LALME) from contemporaneous documents from Cambridgeshire, Norfolk or Suffolk. Instead, he proffered the Central Midlands as a more likely source, partly because many Type 1 documents came from there and there was a literary tradition, partly because the Central Midlands was in the centre of the country and hence not "peripheral" (an objection levelled against the dialect of Norfolk), and partly because the Central Midlands dialect was "progressive and easily understood all over the country" (1989: 74), as well as having good roads south. ${ }^{8}$

There are some assumptions here about what was and was not comprehensible outside a dialect area, about the progressive quality of the Central Midlands dialect, and about transparency in meaning being a property of a central (landlocked) location as opposed to the supposed opacity of the periphery (which

8 I have not summarised here my arguments against the claims of the next scholar in the field, John Fisher (1977, 1979); for these see Wright (1996: 108-109). For a fulsome refutation and rejection of Fisher's claims (and further elucidation of Samuels' types) see Benskin (2004). 
logically ought to apply to all coastal dialects everywhere), but let us turn to why these two great and pioneering manuscript scholars (in whose debt I stand) should have made such claims in the first place. Their versions of events, which are essentially similar in seeking a locus of influence outside London as an explanation for substantial changes in late fourteenth-century London writing, were pre-variationist solutions. Subsequent work in sociolinguistics has shown that variation is a constant, and that dialects consist of ratios of variants, which are expected as default. If ratios of a given feature shift in favour of a feature found in a majority elsewhere, it is no longer automatically assumed that there must have been a movement of speakers from that area. Just as ideas can travel across relatively stable communities, so can linguistic features. The substantial fourteenth-century change perceived by Morsbach, Heuser, Ekwall and Samuels correlated not, I suggest, with a specific exodus of specific people from the Midlands (which has never been identified as such by historians), but with a massive change in Londoners' trading habits (which has), ${ }^{9}$ causing an amount of dialect levelling, ${ }^{10}$ and a corresponding major change in business writing habits.

\section{Taking a multilingual perspective}

Over the last quarter of a century an increasing number of scholars have been considering the dynamic relationship between Anglo-Norman and English, and Medieval Latin and English, and identifying various kinds of contact-induced change. William Rothwell has shown in a large number of publications that the later Anglo-Norman lexis in the British Isles was unlike that of France, that much of the Anglo-Norman word-stock was actually created in Britain and Ireland, and that many French words took on new meanings, unknown in France, in

9 Discussed in Keene (2000), Wright $(2001,2005,2013)$ and not treated further here. Note the difference between exodus (speakers leaving region A and settling permanently in region $\mathrm{B}$ ) and trading (repeated coming and going between regions $\mathrm{A}$ and $\mathrm{B}$ ).

10 Features that levelled include the reduction of adverbial -liche to -ly and the loss of regionally-marked verb plural indicative present-tense $-t h,-n$ and $-s$ and subsequent adoption of zero. Regional are, the th- pronouns, verb third person singular -s and auxiliary do became unmarked universal forms by the end of the sixteenth century, with third person singular $-s$ taking longer to go to completion. Another outcome of dialect contact is the creation of interdialect, where new features develop that did not previously exist: the new universal present participle -ing replaced regionally-marked -and(e), -end(e), -ind(e). 
the British Isles. ${ }^{11}$ Rothwell carefully documented this word by word, and his cumulative body of work shows that Anglo-Norman continued to be productive in Britain from the eleventh to the fifteenth centuries. Christiane Dalton-Puffer (1996) showed that various word-formation affixes hybridised in Britain, giving new hybrid forms not found on the Continent. Their findings beg the question: how did speakers in England come to create new French words so long after the Norman Conquest?

Starting in 1992, I published a series of articles on mixed-language business writing, because that was what I found in archives when I went to look for what people in London, and indeed all England, actually wrote prior to the development of Standard English. ${ }^{12}$ In a number of publications I have been figuring out the regularities of this code-switched mixed-language system, which acted as a written standard all over the country for keeping track of money transactions, at a time when the English dialects (which were very diverse) were not commonly written down. Accounts-keeping sounds like a very limited text-type, but keeping track of money was probably the main motivation for putting quill to parchment, of relevance to everyone who could write. Once alerted to the fact that code-switching was prevalent in business writing, Herbert Schendl searched for code-switched writing in other text-types, including those written before the Norman Conquest. ${ }^{13}$ He established the fact that using French and Latin and English together was indeed a normal medieval practice across the board. The switchpoints, the size and type of the constituents, and the purpose of including other languages varied according to text-type and according to century, but the bald fact that medieval people did not usually write in monolingual English (or monolingual anything, for that matter) is starkly consistent. Written Medieval Latin is informed by the local spoken vernaculars, and it was not until the last quarter of the fifteenth century that any kind of consistent monolingualism emerged.

Richard Ingham documented the ways in which English Anglo-Norman syntax and morphology came to differ from Continental Anglo-Norman syntax and morphology, pinpointing the last generation before divergence as being that of the 1370 s. $^{14}$ Children learning to write Latin at school from 1066 until towards the end of the fourteenth century learnt via the spoken medium of Anglo-Norman French. After that date, written Anglo-Norman in England displays the kind of grammatical levelling which occurs as the result of language

11 For a partial bibliography see Trotter and Gregory (1997: xi-xiv); Schendl and Wright (2011: 19).

12 See Wright (2011: 217-218) for a partial bibliography.

13 See Schendl (2011: 93-94) for a partial bibliography.

14 Ingham (2009a, 2009b, 2010a, 2010b, 2011a, 2011b, 2011c, 2013). 
acquired in adulthood rather than in childhood. Ingham deduced that the use of Anglo-Norman in England as a spoken vehicle for teaching in childhood must have ceased around the end of the fourteenth century, possibly as a result of lack of competent teachers, possibly mitigated by Black Death. Anyone who could write prior to the end of the fourteenth century was trilingual, and this continued to be the case into the fifteenth century, but without the same kind of native-like competence in Anglo-Norman. David Trotter, pondering the difficulties of deciding what was and was not French for the purposes of inclusion in the Anglo-Norman Dictionary, made the observation that le/la/les in Latinmatrix mixed-language writing signalled that the following Noun Phrase was not Latin; that is, that there was a different rule governing use of $l e$ in monolingual Anglo-Norman as used in France (where le changed to la and les according to the gender and number of the noun), to that governing use of le in mixedlanguage writing in England (where le, la and les did not mark gender and number, but gave meta-information about the make-up of the text). ${ }^{15}$ I too found syntactic changes in mixed-language business writing around the end of the fourteenth century, with an increased usage of le, la and les in a Latin matrix and corresponding loss of Latin morphology. Thus, cumulatively and adducing different texts and different sorts of changes, a body of evidence noted by several scholars suggests that there was a sea-change in London writing in the final decades of the fourteenth century, which period of change lasted for a hundred years or so, until monolingual English became customary. What might have caused this period of change?

Professor Caroline Barron, a historian of fourteenth-century London, identified several monolingual English (or multilingual but with sustained passages in monolingual English) civic documents written in the 1370s and 1380s, a time when writing in monolingual English was still a radical choice. ${ }^{16}$ One is a book of City of London ordinances in a late fifteenth-century copy of late fourteenthcentury London English ("the Jubilee Book"); the others are ten English parish guild certificates of 1388. The book of ordinances caused great trouble at the time, and in March 1387, the Court of Common Council (a tier of the City of London's parliament) voted to burn it, causing an outcry from the City craft guilds. Barron hypothesises that the content survives in MS Trinity Coll. Cambridge 0.3.11, which is written in English and is of late fifteenth century date, but with sustained passages copied from a fourteenth-century original. ${ }^{17}$ Writing in

15 Wright (2010a, in press); Trotter (2010: 63). By "meta-information” I mean that le and la preceding the same noun in mixed-language texts signals "monolingual rules do not apply; this is not monolingual ML (or AN)" (Wright 2010a).

16 Barron (2002), Barron and Wright (1995).

17 Written by the Hammond scribe; see Wright (2012) for an analysis of negation strategies. 
English presumably made the content more widely accessible, possibly aggravating the tensions and conflicts in London of the 1370s and 1380s. Barron finds that there was no one single cause for these conflicts ("The more I have studied London in the late fourteenth century, the more convinced I have become that there is no single 'big issue' that caused the turbulence of London in Richard II's reign" [Barron 2002: 1]). She cites shifts in patterns of overseas trade, rise in wages, growth of consumer spending, the drop in population, and rise in living standards all contributing to not just economic conflict, but perhaps also class conflict, and possibly long-term concern about the common good. These first sustained-English civic documents of the 1380s coincide with the first surviving use of passages of monolingual English in the City's records (three proclamations in Letter Book $\mathrm{H}$ from November 1383, following rioting at the October mayoral elections). These documents do not constitute a switch to English per se; rather they constitute the start of the period of transition, because civic documents continued to be written in Medieval Latin and Anglo-Norman for decades to come. It was not a top-down innovation, socially-speaking (as with the "influential and wealthy Midlanders coming to London" theory), nor was it exactly bottom-up (as events of 1381, the Peasant's Revolt, might lead one to expect). Rather, it was an amplification of access to information from being the territory of those who were literate in Medieval Latin and Anglo-Norman (to whatever degree), to those who were not. The citizens who belonged to the parish guilds and craft fraternities cut across the social scale, from City officials belonging to the grander livery companies, to local traders and craftsmen. Women belonged to parish fraternities, and women were traders. Presumably women would have been amongst the "symple \& vnkonnyng men" who would have benefitted from the change to monolingual English. ${ }^{18}$

Finally, I mention the work of José Miguel Alcolado Carnicero, who analysed the records of the Mercers' Livery Company. The Mercers were one of the guilds who protested vigorously against the Jubilee Book reforms, presenting their petition known as the Folk of Mercery in monolingual English. Alcolado Carnicero shows that in the late 1300 s and early 1400s the Mercers' Wardens wrote some of their records in monolingual Medieval Latin, and some in code-switched mixed-language. From 1440 onwards they wrote some of their records in mixedlanguage, and some in monolingual English. But between 1420 and 1440, everything they wrote (or at least, everything that has survived) was in mixedlanguage. Code-switching appears to have been their only linguistic system for these twenty years. They finally shifted to monolingual English in 1464.

18 The phrase comes from the Mercers' complaint to the king known as the Folk of Mercery, 1386 (Chambers and Daunt [1931: 36]). 


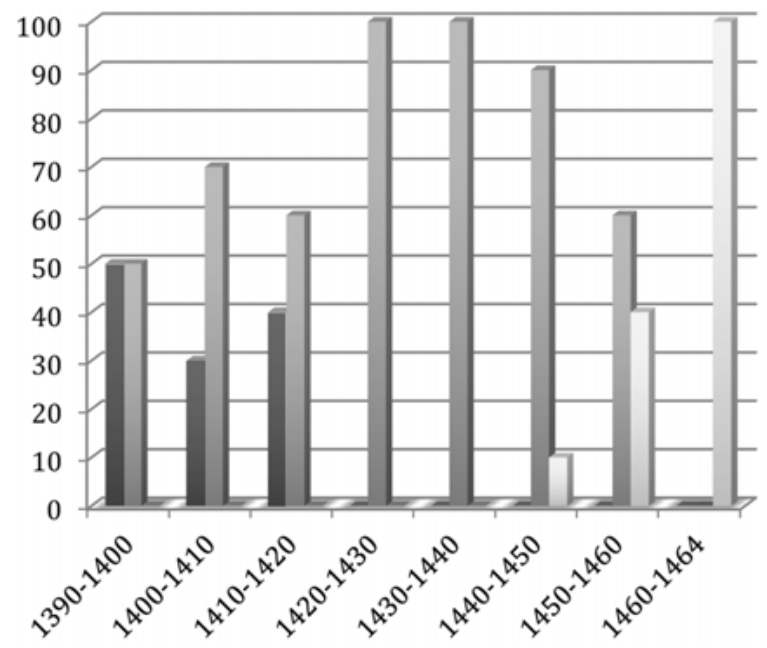

- monolingual Latin/French

mixed-language

- monolingual English

Figure 1: Percentages of Mercers' Wardens' Accounts written in mixed-language and monolingual language. Diagram adapted from Alcolado Carnicero (2013: 217)

A Mercers' clerk starting work in 1400, when the ratio was 30\% monolingual Medieval Latin to $70 \%$ mixed-language documents, and ending his career fifty years later in 1450, when the ratio had shifted to $60 \%$ mixed-language and $40 \%$ monolingual English, might never have composed a monolingual document over a fifty-year career. The transition period was not brief. Resistance to change caused the shift from Latin to English to take a century to go to completion. It was not obvious in 1380 that a hundred years later, everyone would be keeping accounts and business documents in monolingual English. Alcolado Carnicero worked out who those early Mercers' Wardens adopters of language change were, and who their apprentices were (incorporators of more English), and who their apprentices were (incorporators of yet more English). He showed that small groups of specific Mercers led the shift from Latin and French to code-switching, and increased ratios of English. In subsequent work he has shown how looseknit professional networks in general fostered innovation (Alcolado Carnicero 2015). This is a finer-grained approach to the "wealthy and influential citizens" theory of language change, and in this case, certain Mercers' Wardens may indeed have been wealthy and linguistically influential - but they were part of a trend, not its leaders, and other wealthy Mercers' Wardens were less influential. The ten London parish guilds who presented certificates in monolingual (or sustained) English in 1388/9 were self-confessedly not wealthy, nor were their members notably influential, but they were in the van of the shift to English. 
Alcolado Carnicero has highlighted another difficulty with not taking a multilingual perspective: it causes at best unclarity, and at worst misinformation with regard to when the shift to English actually occurred. Just as Wright (1996) pointed out inconsistencies in the various textbook descriptions of the development of Standard English, Alcolado Carnicero (2015) points out inconsistencies in various datings of the shift to English. This is partly due to the Chinese-whispers effect of scholar repeating scholar and introducing error at some point along the chain, but mainly because there has been no distinction between the partial shift to English at the tip-point with subsequent documents in the archive then reverting to monolingual Latin, French or mixed-language; and total shift, at which the point of no return had been reached, and the tip-point passed. ${ }^{19}$

\section{Conclusion}

Pulling the above observations together, the transition period is characterised by:

a) morphological and phonological changes in monolingual London English between the fourteenth and fifteenth centuries (identified by Morsbach, Heuser, Ekwall, Samuels)

b) syntactic and morphological changes in British Anglo-Norman starting in the 1370s (identified by Ingham)

c) changes in mixed-language writing: le/la increase and commensurate loss of Latin morphology in the NP, increase in ratios of English NPs, increasing analytic word-order, and when the tip-point was finally reached (which varies from archive to archive), transgression of the syntactic switchpoint norms (identified by Wright)

d) the first monolingual English texts, or sustained passages of monolingual English, from the 1380s (e.g. those in Chambers and Daunt [1931]; the guild certificates and Jubilee Book text identified by Barron)

e) a period of code-switching as a norm, buffering between monolingual Medieval Latin and monolingual Proto-Standard English (identified by Alcolado Carnicero)

f) a period of political and social disruption in London in the 1370s and 1380s (of multiple causation, discussed by Barron)

g) a period of massive change in Londoners' trading patterns between the fourteenth and fifteenth centuries, from dealing with people in the surrounding hinterland, to dealing with countrywide networks and foreign merchants who made repeat visits to London (Keene [2000] and colleagues, summarised in Wright [2013]).

19 See Wright (2015) for more on the recent work of the scholars discussed in this section. 
Collectively, the transition period provides an answer to the question begged by Rothwell's finding that French words continued to be coined in England into the fifteenth century. A search of the Oxford English Dictionary yields 4,328 English words of French origin first attested between 1400-1500, a time when there were few mother-tongue speakers of French in England. Some of these may have been coined earlier, but this number allows the inference that French was still actively and productively used in England during this century. It is visible via the medium of mixed-language writing, and it is one of the reasons why mixed-language writing in general and the transition phase in particular is vital for understanding the development of Standard English. Standard English was an outcome of socioeconomic change, not in an "exodus from the Midlands" scenario, nor in an "imposition of Chancery house-style" scenario, but as a result of vastly increased weak-tie exchanges with people from elsewhere in Britain and the Continent. Levelling was one result (see footnote 10 above), but it is not the whole story. Trudgill (2009) sees non-levelled features such as thirdperson singular $-s$, or the inflected genitive phrase (butlars frocke, as opposed to northern butlar frocke) as an arrested - or perhaps just greatly delayed - drift towards analogical regularisation. ${ }^{20}$ Hope (2000) sees it as a feature of written high-register language; that that which is high-register must be differentiated on the page from that which is low-register, and use of linguistically-unlikely features achieves this. But such matters were resolved considerably after the transition phase and the switch to Proto-Standard English. Proto-Standard English, as written around the country, still awaits detailed description. ${ }^{21}$

\section{References}

\section{Manuscripts}

Guildhall Library, London. MS 2596/1. St Mary Magdalen Milk Street Cash Book, 1518-1606, Churchwardens' Accounts.

The National Archive, Kew, MS E101/509/19, Gilbert Maghfeld: A Merchant's book of his debts, 25 January 1372-21 June 1395.

The National Archive, Kew, MS E122 194/25, Port of London Petty Customs Account. (Published in Cobb 1990)

Wren Library, Cambridge, MS Trinity Coll. Cambridge 0.3.11.

20 For the uninflected genitive in London see Wright (2010b: 182-187); for a discussion of Trudgill's (2009) position, see Wright (2013). I am grateful to Julia Fernández Cuesta for raising the example of the inflected genitive phrase; see her discussions in Fernández Cuesta and Rodríguez Ledesma (2008, 2009).

21 See Anita Auer’s "Emerging Standards” project: http://www.emergingstandards.eu/. 


\section{Printed texts}

Alcolado Carnicero, José Miguel. 2013. Social networks and mixed-language business writing: Latin/French/English in the wardens' accounts of the Mercers' Company of London, 13901464. Albacete: University of Castilla-La Mancha dissertation.

Alcolado Carnicero, José Miguel. 2015. Dating the shift to English in the financial accounts of some London livery companies: A reappraisal. Multilingua. 34(3). 373-404.

Barron, Caroline. 2002. The burning of the Jubilee Book. http://www.guildhallhistoricalassociation. org.uk/docs/The\%20burning\%20of\%20the\%20Jubilee\%20Book\%201376-1387.pdf (accessed 21 November 2014).

Barron, Caroline Mary \& Laura Wright. 1995. The London Middle English guild certificates of 1388-9. Nottingham Medieval Studies 39. 108-145.

Benskin, Michael. 2004. Chancery Standard. In Christian Kay, Carole Hough \& Irené Wotherspoon (eds.), New perspectives on English historical linguistics: Selected papers from 12 ICEHL, Glasgow, 21-26 August 2002, vol. II: Lexis and transmission (Current Issues in Linguistic Theory 252), 1-40. Amsterdam \& Philadelphia: John Benjamins.

Chambers, R. W. \& Marjorie Daunt. 1931. A book of London English, 1384-1425. Oxford: Clarendon Press.

Clyne, Michael. 1967. Transference and triggering: Observations on the language assimilation of postwar German-speaking migrants in Australia. The Hague: Martinus Nijhoff.

Clyne, Michael. 1991. Community languages: The Australian experience. Cambridge: Cambridge University Press.

Clyne, Michael. 2003. Dynamics of language contact: English and immigrant languages. Cambridge: Cambridge University Press.

Cobb, Henry S. (ed.). 1990. The overseas trade of London Exchequer customs accounts 14801481 (London Record Society Publications 27). London: London Record Society.

Dalton-Puffer, Christiane. 1996. The French influence on Middle English morphology: A corpusbased study of derivation (Topics in English Linguistics 20). Berlin \& New York: Mouton de Gruyter.

Dorian, Nancy C. 1978. East Sutherland Gaelic. Dublin: Dublin Institute for Advanced Studies.

Dorian, Nancy C. 1981. Language death: The life cycle of a Scottish Gaelic dialect. Philadelphia, PA: University of Pennsylvania Press.

Ekwall, Bror Eilert. 1956. Studies on the population of medieval London. Stockholm: Almqvist \& Wiksell.

Fernández Cuesta, Julia \& Maria Nieves Rodríguez Ledesma. 2008. Northern Middle English: Towards telling the full story. In Marina Dossena, Richard Drury \& Maurizio Gotti (eds.), English historical linguistics 2006, vol. III: Geo-historical variation in English (Current Issues in Linguistic Theory 297), 91-109. Amsterdam \& Philadelphia: John Benjamins.

Fernández Cuesta, Julia \& Maria Nieves Rodríguez Ledesma. 2009. The northern echo: Continuities in contemporary Northern English. In Marina Dossena \& Roger Lass (eds.), Studies in English and European historical dialectology (Linguistic Insights: Studies in Language and Communication 98), 157-189. Bern: Peter Lang.

Fisher, John Hurt. 1977. Chancery and the emergence of standard written English in the fifteenth century. Speculum 52(4). 870-899.

Fisher, John Hurt. 1979. Chancery Standard and modern written English. Journal of the Society of Archivists 6. 136-144. 
Furnivall, Frederick J. (ed.). 1882. Fifty earliest English wills in the Court of Probate, London: A. D. 1387-1439 (Early English Text Society Original Series 78). London: Oxford University Press.

Heuser, Wilhelm. 1914. AltLondon: Mit besonderer Berücksichtigung des Dialekts. Osnabrück: Liesecke.

Hope, Jonathan. 2000. Rats, bats, sparrows and dogs: Biology, linguistics and the nature of Standard English. In Laura Wright (ed.), The development of Standard English 1300-1800: Theories, descriptions, conflicts (Studies in English Language), 49-56. Cambridge: Cambridge University Press.

Ingham, Richard. 2009a. Mixing languages on the manor. Medium Avvum 78(1). 80-97.

Ingham, Richard. 2009b. The persistence of Anglo-Norman 1230-1362: A linguistic perspective. In Jocelyn Wogan-Browne (ed.), Language and culture in medieval Britain: The French of England c.1100-c.1500, 44-54. Woodbridge: York Medieval Press \& The Boydell Press.

Ingham, Richard. 2010a. Later Anglo-Norman as a contact variety of French? In Richard Ingham (ed.), The Anglo-Norman language and its contexts, 8-25. Woodbridge: Boydell.

Ingham, Richard. 2010b. The transmission of Anglo-Norman. In Richard Ingham (ed.), The Anglo-Norman language and its contexts, 164-182. Woodbridge: York Medieval Press \& The Boydell Press.

Ingham, Richard. 2011a. Code-switching in the later medieval English lay subsidy rolls. In Herbert Schendl \& Laura Wright (eds.), Code-switching in early English (Topics in English Linguistics 76), 95-114. Berlin \& Boston: Mouton de Gruyter.

Ingham, Richard. 2011b. Grammar change in Anglo-Norman and continental French: The replacement of non-assertive indefinite nul by aucun. Diachronica 28(4). 441-467.

Ingham, Richard. 2011c. The decline of bilingual competence in French in medieval England: Evidence from the PROME database. In Nils Langer, Steffan Davies \& Wim Vandenbussche (eds.), Language and history, linguistics and historiography: Interdisciplinary approaches (Studies in Historical Linguistics 9), 71-292. Bern: Peter Lang.

Ingham, Richard. 2013. Language-mixing in medieval Latin documents: Vernacular articles and nouns. In Judith A. Jefferson \& Ad Putter (eds.), Multilingualism in medieval Britain (c.1066-1520): Sources and analysis (Medieval Texts and Cultures of Northern Europe 15), 105-121. Turnhout: Brepols.

Keene, Derek. 2000. Metropolitan values: Migration, mobility and cultural norms, London 11001700. In Laura Wright (ed.), The development of Standard English, 1300-1800: Theories, descriptions, conflicts (Studies in English Language), 93-114. Cambridge: Cambridge University Press.

LALME = McIntosh, Angus, M. L. Samuels \& Michael Benskin with the assistance of Margaret Laing \& Keith Williamson. 1986. A Linguistic Atlas of Late Mediaeval English, 4 vols. Aberdeen: Aberdeen University Press.

Lass, Roger. 1992. Phonology and morphology. In Norman Blake (ed.), The Cambridge history of the English language, vol. 2: 1066-1476, 23-155. Cambridge: Cambridge University Press.

Lass, Roger. 1999. Phonology and morphology. In Roger Lass (ed.), The Cambridge history of the English language, vol. 3: 1476-1776, 56-186. Cambridge: Cambridge University Press.

Metcalfe, Caroline A. 2014. William Porlond, Clerk to the Craft and Fraternity of Brewers of London, 1418-1440. Transactions of the London and Middlesex Archaeological Society 65. 267-284.

Middle English Dictionary. http://quod.lib.umich.edu/m/med/. 
Miller, D. Gary. 1997. The morphological legacy of French borrowed suffixes on native bases in Middle English. Diachronica 14(2). 233-264.

Morsbach, Lorenz. 1888. Über den Ursprung der neuenglischen Schriftsprache. Heilbroun: Henninger.

Myers-Scotton, Carol. 1993. Duelling languages: Grammatical structure in codeswitching. Oxford: Clarendon Press.

Nevalainen, Terttu \& Helena Raumolin-Brunberg (eds.). 1996. Sociolinguistics and language history: Studies based on the Corpus of Early English Correspondence. Amsterdam \& Atlanta: Rodopi.

OED = Oxford English Dictionary. http://www.oed.com.

Picone, Michael D. 1994. Code-intermediate phenomena in Louisiana French. In Katharine Beals, Jeannette Denton, Robert Knippen, Lynette Melnar, Hisami Suzuki \& Erica Zeinfeld (eds.), CLS 30: Papers from the 30th Regional Meeting of the Chicago Linguistic Society, vol. 1, 320-334. Chicago: Chicago Linguistic Society.

Samuels, Michael Louis. [1963] 1989. Some applications of Middle English dialectology. English Studies 44. 81-94. Reprinted in Angus McIntosh, Michael Louis Samuels \& Margaret Laing (eds.). 1989. Middle English dialectology: Essays on some principles and problems, 6480. Aberdeen: Aberdeen University Press.

Schendl, Herbert. 2011. Beyond boundaries: Code-switching in the leases of Oswald of Worcester. In Herbert Schendl \& Laura Wright (eds.), Code-switching in early English (Topics in English Linguistics 76), 47-94. Berlin \& Boston: Mouton de Gruyter.

Schendl, Herbert \& Laura Wright. 2011. Code-switching in early English: Historical background and methodological and theoretical issues. In Herbert Schendl \& Laura Wright (eds.), Code-switching in early English (Topics in English Linguistics 76), 15-45. Berlin \& Boston: Mouton de Gruyter.

Trotter, David A. 2010. Bridging the gap: The (socio)linguistic evidence of some medieval English bridge accounts. In Richard Ingham (ed.), The Anglo-Norman language and its contexts, 52-63. Woodbridge: York Medieval Press \& The Boydell Press.

Trotter, David A. \& Stewart Gregory (eds.). 1997. De mot en mot: Aspects of medieval linguistics. Essays in honour of William Rothwell. Cardiff: The University of Wales Press in conjunction with the Modern Humanities Research Association.

Trudgill, Peter. 2009. Vernacular universals and the sociolinguistic typology of English dialects. In Markku Filppula, Juhani Klemola \& Heli Paulasto (eds.), Vernacular universals and language contacts: Evidence from varieties of English and beyond, 302-320. London: Routledge.

Wright, Laura. 1996. About the evolution of Standard English. In Elizabeth M. Tyler \& M. Jane Toswell (eds.), Studies in English language and literature: 'Doubt Wisely'. Papers in honour of E. G. Stanley, 99-115. London: Routledge.

Wright, Laura. 2001. The role of international and national trade in the standardisation of English. In Isabel Moskowich-Spiegel Fandiño, Begoña Crespo Garcia, Emma Lezcano Gonzalez \& Begoña Simal Gonzalez (eds.), Re-interpretations of English: Essays on language, linguistics and philology, vol. 1, 189-207. A Coruña: Universidade da Coruña.

Wright, Laura. 2002. Code-intermediate phenomena in medieval mixed-language business texts. Language Sciences 24. 471-489.

Wright, Laura. 2005. Medieval mixed-language business texts and the rise of Standard English. In Janne Skaffari, Matti Peikola, Ruth Carroll, Risto Hiltunen and Brita Wårvik (eds.), Opening windows on texts and discourses of the past (Pragmatics and Beyond New Series 134), 381-399. Amsterdam \& Philadelphia: John Benjamins. 
Wright, Laura. 2010a. A pilot study on the singular definite articles $l e$ and $l a$ in fifteenth-century London mixed-language business writing. In Richard Ingham (ed.), The Anglo-Norman language and its contexts, 130-142. Woodbridge: York Medieval Press \& The Boydell Press.

Wright. 2010b. Eighteenth-century London non-standard spellings as evidenced by servants', tradesmen's and shopkeepers' bills. In Nicholas Brownlees, Gabriella Del Lungo \& John Denton (eds.), The language of public and private communication in a historical perspective, 161-190. Cambridge: Cambridge Scholars Publishing.

Wright, Laura. 2011. On variation in medieval mixed-language business writing. In Herbert Schendl \& Laura Wright (eds.), Code-switching in early English (Topics in English Linguistics 76), 191-218. Berlin \& Boston: Mouton de Gruyter.

Wright, Laura. 2012. The Hammond scribe: His dialect, his paper, and folios 133-155 of Trinity College Cambridge MS 0.3.11. In Claudia Lange, Beatrix Weber \& Göran Wolf (eds.), Communicative spaces: Variation, contact, and change, 227-258. Frankfurt am Main: Peter Lang.

Wright, Laura. 2013. The contact origins of Standard English. In Daniel Schreier \& Marianne Hundt (eds.), English as a contact language (Studies in English Language), 58-74. Cambridge: Cambridge University Press.

Wright, Laura. 2015. On medieval wills and the rise of written monolingual English. In Javier Calle Martin and \& Camilo Conde Silvestre (eds.), Approaches to Middle English: Contact, variation and change, 35-54. Frankfurt am Main: Peter Lang.

Wright, Laura. In press. On non-integrated vocabulary in the mixed-language Accounts of St Paul's Cathedral, 1315-1405. In Richard Ashdowne \& Carolinne White (eds.), Latin in Medieval Britain. London: British Academy. 